Official Publication of the Indian Pharmacological Society

October 2007 Vol $39 \quad$ Issue 5

\section{Indexed / Listed in}

Science Citation Index, Journal Citation Report, Biological Abstracts/Biosis, Chemical Abstracts, EMBASE/Excerpta Medica, CAB Abstract, Global Health, Excerpta Medicinal and Aromatic Plants Abstracts, Health \& Wellness Research Center, Health Reference Center Academic, InfoTrac One File, Expanded Academic ASAP, NCI Current Contents, Indian Science Abstracts, IndMed, and Medind.

\section{Publication}

The journal is published six times in a year in the months of February, April, June, August, October and December.

\section{Copyright and Photo-copying}

No part of this publication may be reproduced or transmitted in any form or by any means, electronic or mechanical, including photocopy without permission in writing from the Chief Editor.

\section{Correspondence}

Enquiries should be addressed to the Chief Editor.

\section{Disclaimer}

The Chief Editor disclaims any responsibility for statements made and opinions expressed by authors or claims made by the advertisers.

\section{Disputes}

Readers, contributors, members and advertisers may approach the President, IPS, in case of disputes with the IJP.

The journal is printed on acid free paper

\section{IPS Members}

The issues are supplied for Rs. 5.00 to members in India. Members residing overseas can get the issues on payment of US\$ 25/ annum towards airmail charges.

\section{Missing Issues}

Claims for missing issues should be sent within 2 months of issue date.

\section{Published by}

Medknow Publications

A-109, Kanara Business Centre, Off Link Road, Ghatkopar (E), Mumbai - 400075,

India. Phone: 91-22-6649 1818/1816,

Fax: 91-22-6649 1817,

Web: www.medknow.com

\section{Websites}

www.ijp-online.com

www.journalonweb.com/ijp

www.bioline.org.br/ph

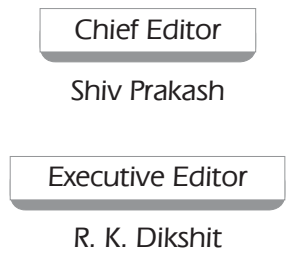

\begin{tabular}{|c|}
\hline Associate Editor \\
Varsha Patel
\end{tabular}

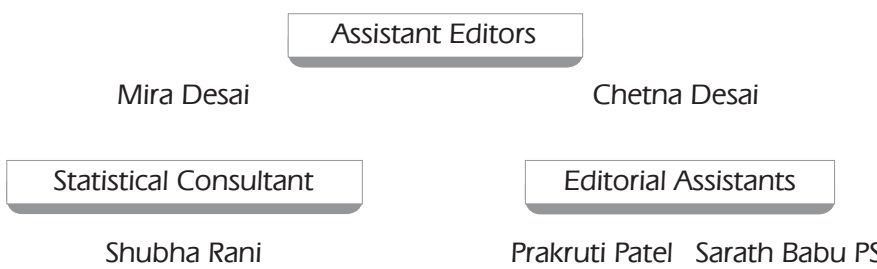

\begin{tabular}{ll}
\cline { 2 - 2 } & \multicolumn{1}{c}{ International Advisory Board } \\
\cline { 2 - 2 } Adithan C, India & Anil Gulati, USA \\
Bhaskar Jasti, USA & Diwan PV, India \\
Ding Jian, China & Gupta JB, India \\
Gambhir SS, India & Gupta YK, India \\
Jagadish G, USA & Lennard MS, UK \\
Manjeet Singh, India & Mario A. Gonzalez, USA \\
Mehendale HM, USA & Naidu MUR, India \\
Nanivadekar AS, India & Narayana DBA, India \\
Ozturk Y, Turkey & Pipasha Biswas, UK \\
Rao V.S.V. Vadlamudi, India & Uthai Suvanakoot, Thailand
\end{tabular}

Editorial Board

Arunabha Ray, Delhi

Dinesh Kumar, Hyderabad

Jagadeesh K, Davangere

Kulkarni SK, Chandigarh

Malik JK, Izatnagar

Mody SK, Sardar Krushinagar

Moulik SK, Delhi

Pundarikakshadu K, Ahmedabad

Rama Rao P, Chandigarh

Ramesh K. Goyal, Ahmedabad

Seshagiri Rao C, Hyderabad

Sushma Mengi, Mumbai

Thatte UM, Mumbai

G. Parthasarathy, Mysore
Bhupendra Singh Bhoop, Chandigarh

Flora SJS, Gwalior

Katiyar CK, Delhi

Madhu Dikshit, Lucknow

Mallikarjuna Rao C, Manipal

Mohanasudaram J, Chennai

Nilima Kshirsagar, Mumbai

Rajan Vedasiromani J, Kolkata

Ramkishan A, Ahmedabad

Roy BK, Ranchi

Shankarnarayana A, Coimbatore

Tripathi SK, Kolkata

Usharani P, Hyderabad

RS Bhatia, Ludhiana 


\section{Indian Journal of Pharmacology}

Official Publication of the Indian Pharmacological Society

October 2007 Vol 39 Issue 5

\section{CONTENTS}

\section{Editorial}

Irrational combinations: No consideration for patient safety: Shiv Prakash

\section{Review Article}

Bioequivalence: Issues and perspectives: Shubha Rani

\section{Research Papers}

Isolation, characterization and study of enhancing effects on nasal absorption of insulin in rat of the total saponin from Acanthophyllum squarrosum: S.A. Sajadi Tabassi, H. Hosseinzadeh, M. Ramezani, E. Moghimipour, S.A. Mohajeri

Pharmacological and biochemical evidence for the antidepressant effect of the herbal preparation Trans-01: Md. Shalam, S.M. Shantakumar, M. Laxmi Narasu

Effects of dexamethasone and betamethasone as COX-2 gene expression inhibitors on rigidity in a rat model of Parkinson's disease: Mehdi Shafiee Ardestani, Hassan Mehrab, Nourallah Sadeghzadeh

Activity of aqueous ethanol extract of Euphorbia prostrata ait on Shigella dysenteriae type 1-induced diarrhea in rats:

Kamgang René, Gonsu Kamga Hortense, Wafo Pascal, Mbungni N. Jean Alexis, Pouokam Ervice Vidal,

Fokam Tagne Michel Archange, Fonkoua Marie Christine

Antidiarrheal and antimicrobial activities of Stachytarpheta jamaicensis leaves: S. Sasidharan, L. Yoga Latha, Z. Zuraini, S. Suryani, S. Sangetha, L. Shirley

\section{Research Letters}

Positive inotropic and chronotropic effect of aloe gel on isolated rat heart: Pradeep Kumar, Manish Goyal, Sunita Tewari

Synergistic effect of cefixime and cloxacillin combination against common bacterial pathogens causing community acquired pneumonia: Astha Agarwal, N. Jain, A. Jain

In vitro cytotoxic and human recombinant caspase inhibitory effect of Annona reticulata leaves: Susanta Kumar Mondal, Nirup Bikash Mondal, Upal Kanti Mazumder

\section{Correspondence}

Counterfeit and substandard drugs: The need for an effective and stringent regulatory control in India and other developing countries: A. Sukhlecha

\section{Letter to the Editor}

Postgraduate education in medical pharmacology: A student's viewpoint: Varun Gupta

\footnotetext{
The copies of the journal to members of the association are sent by ordinary post. The editorial board, association or publisher will not be responsible for non-receipt of copies. If any of the members wish to receive the copies by registered post or courier, kindly contact the journal's / publisher's office. If a copy returns due to incomplete, incorrect or changed address of a member on two consecutive occasions, the names of such members will be deleted from the mailing list of the journal. Providing complete, correct and up-to-date address is the responsibility of the members. Copies are sent to subscribers and members directly from the publisher's address; it is illegal to acquire copies from any other source. If a copy is received for personal use as a member of the association/society, one cannot resale or give-away the copy for commercial or library use.
} 


\title{
Activity of aqueous ethanol extract of Euphorbia prostrata ait on Shigella dysenteriae type 1-induced diarrhea in rats
}

\author{
Kamgang René, Gonsu Kamga Hortense ${ }^{1}$, Wafo Pascal ${ }^{2}$, M bungni N. J ean Alexis, Pouokam Ervice Vidal, \\ Fokam Tagne M ichel Archange, Fonkoua M arie Christine ${ }^{3}$
}

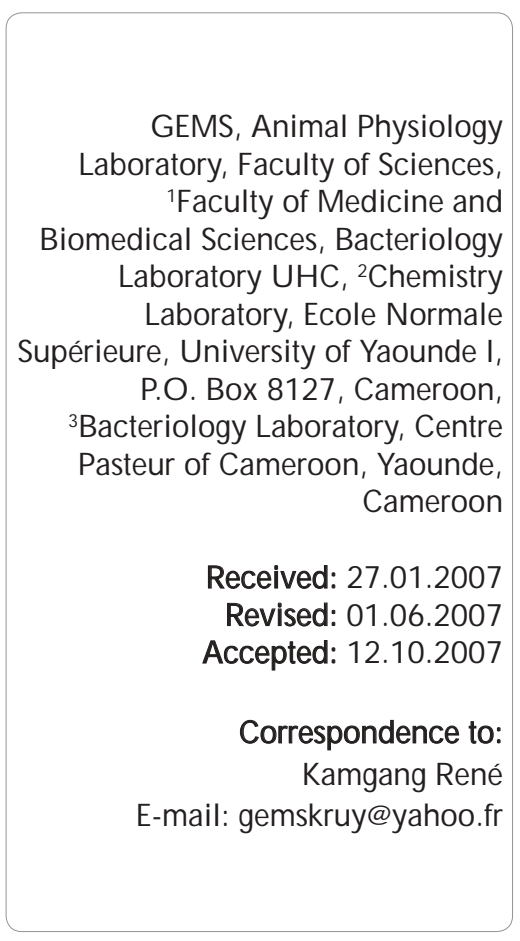

\section{ABSTRACT}

Aim: Euphorbia prostrata (Euphorbiaceae) is traditionally used in Cameroon for the treatment of many diseases, including diarrhea. We investigated the acute toxicity and effect of the aqueous ethanol extract of the plant on gastrointestinal propulsion, in vitro bacterial growth and in vivo bacillary dysentery.

Materials and Methods: Diarrhea was induced by oral administration of $12 \times 10^{8}$ Shigella dysenteriae type 1 (Sd1) cells. Diarrheic rats were treated for 5 days with 10,20 or $40 \mathrm{mg} / \mathrm{kg}$ extract or $20 \mathrm{mg} / \mathrm{kg}$ norfloxacin. The faeces frequencies and the number of $S d 1$ were assessed and the death rate recorded.

Results: The aqueous ethanol extract of $E$. prostrata was not toxic. In vitro, the minimal inhibitory and minimal bactericidal concentrations of the extract were 3,500 and $12,000 \mu \mathrm{g} / \mathrm{ml}$, respectively. In vivo, diarrhea went along with increase in faeces frequency $\left(P<0.01\right.$ by the $3^{\text {rd }}$ day $)$, increase in the bacterial population to a maximum on the $2^{\text {nd }}$ day after infection $(P<0.01)$. The death rate in diarrheic control group was $100 \%$ by day 6. E. prostrata extracts ( 20 and $40 \mathrm{mg} / \mathrm{kg}$ ), like norfloxacin, reduced the bacterial growth $(P<0.01)$, so that by the $6^{\text {th }}$ day $S d 1$ density was $<100$ and no death was recorded. There was a significant $(P<0.01)$ reduction in faeces frequencies. The extract exhibited notable $(P<0.01)$ inhibition of intestinal propulsion.

Conclusion: The results suggest that $E$. prostrata possesses bactericidal and antidiarrheic properties and could be a therapeutic alternative for diarrheas of bacterial etiology.

KEY WORDS: Antidiarrheic activity, Euphorbia prostrate, rat, Shigella dysenteriae type 1
Diarrhea is responsible for 3.1 million deaths monthly the world over, with more than 600,000 due to shigellosis. ${ }^{[1]}$ Shigella dysenteriae type $1(\mathrm{Sd} 1)$ is an endemic human pathogen, causing acute bacillary dysentery in regions with high population densities. Resistance to quinolone antibiotics has been reported for this organism which rapidly develops resistance to the current therapy ${ }^{[2-4]}$ Foreign multidrug-resistant Sd1 strains might be introduced into new communities through travel. Dominant clones of ciprofloxacin-resistant Sd1 were observed in Southeast Asia and in Canada. ${ }^{[5-7]}$ In sub-Saharan Africa, factors like refugee camps, rainy season and hot climate favour shigellosis due to $\mathrm{Sd1} .^{[8]}$ In Ngoela, East Cameroon, a $16.4 \%$ fatality rate of Sd1-Escherichia coli 0157-Entamoeba histolytica-induced diarrhea was recorded..$^{[9]}$ Many Sd1 strains in this African region are resistant to most of the antibiotics generally available in rural health centres. ${ }^{[10]}$ Effective medicinal molecules (fluoroquinolones, aminoglycosides, etc) are exceptional and less accessible (due to high cost). The resistance profile leaves few reliable and economical therapeutic options for Sd1. In Africa, some medicinal plants are currently used against bacillary dysentery. ${ }^{[11,12]}$ In the central, eastern, southern and western rural parts of Cameroon, Euphorbia prostrata (Euphorbiaceae) is very often used for the treatment of dysentery. This plant contains flavonoid and phenolic compounds and was demonstrated to have anti-inflammatory and analgesic properties. ${ }^{[13,14]}$ In the traditional use for diarrhea treatment, a handful of fresh plant is boiled in $500 \mathrm{ml}$ water for 15-20 min. The decoction (supernatant) is drunk: a teaspoonful $(\approx 5 \mathrm{ml})$ for infant and half a teacup $(\approx 125 \mathrm{ml})$ for adults are recommended twice a day.

In the present work, we undertook a study to verify the claim of the medicinal value of $E$. prostrata, in a model of human bacillary dysentery induced in rats.

\section{Materials and Methods}

\section{Animals used for the experiment}

Three-month old albino mice (weighing 20-30 gm) and Wistar rats (weighing 170-210 gm) of either sex, bred in our animal house in the ambient environmental conditions, were used for toxicity and antimicrobial drug assessment, respectively. Animal housing and experiments in vivo were done according to the guidelines of the European Union on Animal Care (CEE Council 86/609) 
that was adopted by the Institutional Committee of the Ministry of Scientific Research and Innovation of Cameroon. These animals were allowed water and food ad libitum. Rats were kept singly in metabolic cages. Diarrhea was induced in rats according to the method described earlier, using Shigella dysenteriae type 1 (Sd1) strain provided by the Centre Pasteur of Yaoundé, Cameroon. ${ }^{[15,16]}$ For this purpose, after verifying that the rats were not $\mathrm{Sd} 1$ carriers, each rat in the 5 groups (of 5 animals each) was orally administered $12 \times 10^{8}$ (the 4 McFarland standard) saline-diluted Sd1 cells.

\section{Plant material and extract}

The whole plant of Euphorbia prostrata Ait was collected in Yaoundé, Cameroon and identified by the National Herbarium of Cameroon at Yaoundé, where a voucher specimen was deposited (Reference 65 596/HNC). The whole aerial part was washed thoroughly with water, shade dried and ground; $1.5 \mathrm{~kg}$ of the powder was macerated for 4 days in $80 \%$ ethanol $(5 \mathrm{~L}$ ). The filtrate was evaporated to dryness in a rotary evaporator at $37^{\circ} \mathrm{C}$ to yield $85 \mathrm{gm}$ of dark green E. prostrata extract, which was subsequently dissolved in 1\% DMSO.

\section{Acute toxicity}

The acute toxicity of the extract was evaluated in 56 normal albino mice separated into 7 groups of 8 mice each $(4$ males and 4 females). Each group was fasted for $24 \mathrm{~h}$, after which they were treated once orally with one of the increasing doses of the extract: $0,5,10,15,20,25$ or $30 \mathrm{gm} / \mathrm{kg}$ bw; the volume of each administered dose did not exceed $1 \mathrm{ml}$. The mice were then observed for at least $48 \mathrm{~h}$ and up to 7 days, for death, lethargy, jerkiness, sensitiveness to noise and touch, stools quality and frequency. The dose of the extract that would kill $50 \%$ of the animal population $\left(\mathrm{LD}_{50}\right)$ by the route given was estimated graphically or by using the following formula: ${ }^{[17]}$

$$
\mathrm{LD}_{50}=\mathrm{X}_{\mathrm{s}}-\mathrm{d}\left(\sum \mathrm{p}-1 / 2\right)
$$

$X_{s}: 100 \%$ lethal dose; d: interval between 2 successive doses; p: death ratio per group.

\section{Preliminary phytochemical screening test}

Screening of the phytochemical properties of the aqueous ethanol extract of $E$. prostrata was done using the following chemicals and reagents: ${ }^{[18,19]}$ Mayer and freshly prepared Dragendoff's reagents (for alkaloids), Liebermann-Buchard test (for terpenoids and sterols), $\left[\mathrm{FeCl}_{3}\right.$ and $\left.\mathrm{K}_{3} \mathrm{Fe}(\mathrm{CN})_{6}\right]$ (for phenols and tannins), Shinoda test [(magnesium turnings and $\mathrm{K}_{3} \mathrm{Fe}(\mathrm{CN})_{6}$ ] (for flavonoids), Molish test ( $\alpha$-naphtol and $\mathrm{H}_{2} \mathrm{SO}_{4}$ ) (for polysaccharides), frothing test (for saponins), $\mathrm{FeCl}_{3}$ and $\mathrm{HCl}$ (for phlobotannins) and $\mathrm{NH}_{4} \mathrm{OH}$ (for anthraquinones).

In vitro antimicrobial activity: The antimicrobial activities of aqueous ethanol extracts of $E$. prostrata were tested using both serial dilution in broth and agar diffusion methods. Sd1 inocula were standardized by matching the turbidity of the culture to the 0.5 McFarland standard, as recommended by the National Committee of Clinical and Laboratory Standards (Indiana, U.S.A.). ${ }^{[201}$ Bacterial suspensions were further diluted to obtain the $5 \times 10^{5} \mathrm{CFU}$ inoculum. In the agar diffusion method, $500 \mu \mathrm{l}$ Sd1 inocula was seeded over Mueller-Hinton II (Boetec) agar. The well technique was used and each well was filled with $200 \mu \mathrm{l}$ of each drug solution: standard antibiotic for control (norfloxacin $5 \mu \mathrm{g})$, increasing doses of $\mathrm{E}$. prostrata extract $(0.01-200 \mathrm{mg})$ and $1 \%$ DMSO as negative control. After $18 \mathrm{~h}$ incubation at $37^{\circ} \mathrm{C}$, the inhibition diameters $(\varnothing$; in $\mathrm{mm})$ against $\mathrm{Sd} 1$ were determined using a caliper square. The minimal inhibitory concentration (MIC) was defined as the lowest concentration of antimicrobial extract that prevented visible growth. This was confirmed spectrophotometrically and by a count of viable cells on Hektoen (Becton Dickinson and Company) agar. ${ }^{[2,221}$ The minimal bactericidal concentration (MBC) was determined as the lowest concentration of extract allowing only $0.01 \%$ survival for Sd1. Each test was repeated three times.

\section{In vivo antidiarrheic activity}

Antimicrobial activity: Diarrheic rats were randomly divided into 5 groups, each containing 5 animals. When diarrhea appeared, animals were administered the antidiarrheic drugs twice daily by the oral route (using an orogastric tube) for 5 consecutive days: the first group (diarrheic control) received vehicle (1\% DMSO); the second group received the antibiotic norfloxacin (Noroxine, Laboratory Merck Sharp and Dohme-Chibret MSD, Paris) $20 \mathrm{mg} /$ $\mathrm{kg}$; and groups 3-5 received 10,20 and $40 \mathrm{mg} / \mathrm{kg}$ E. prostrata extract, respectively, with the aim to be as close as possible to the doses of the extract used traditionally (estimated at $20 \mathrm{mg} / \mathrm{kg}$ bw of extract for $60 \mathrm{~kg}$ adult). To make sure that the food given to the animals was not implicated as the cause of diarrhea, a group of 5 normal rats was used as negative control, receiving neither bacterial inoculum nor drug but only food and water. Stools were collected using a white cloth fixed under the bars supporting the animals in the metabolic cage. The frequencies of faeces were evaluated for 6 consecutive days following $\mathrm{Sd} 1$ administration. Enumeration of $\mathrm{Sd} 1$ in faeces was performed before the induction of diarrhea and after the appearance of diarrhea at 2, 26, 50, 74, 98 and $122 \mathrm{~h}$. For this purpose, $0.5 \mathrm{gm}$ faeces was homogenized in $4.5 \mathrm{ml}$ sterile saline; serial dilutions were made and $500 \mu \mathrm{l}$ of each dilution was seeded over Hektoen agar. After $24 \mathrm{~h}$ incubation at $37^{\circ} \mathrm{C}$, the number of $\mathrm{CFU}$ was determined..$^{[22,23]}$ Animals were observed for 7 days from the day on which diarrhea was induced and the death rate was recorded.

Gastrointestinal propulsion: Rats in groups of 5 each were fasted for $48 \mathrm{~h}$ with free access to water. Each animal was administered per os $0.5 \mathrm{ml}$ of a charcoal suspension $(5 \%$ charcoal powder in $10 \%$ Arabic gum) in water. Each rat received orally, 30 min prior to the administration of the charcoal meal, one of the two doses of $E$. prostrata extract: 40 or $60 \mathrm{mg} / \mathrm{kg} \mathrm{bw}$. The control group received an equal volume of $1 \%$ DMSO. Half an hour after the meal, the rats were sacrificed and the percentage length of intestine traversed by the charcoal solution from the pylorus to the caecum was determined. ${ }^{\mid 24]}$

\section{Statistical analysis}

The results are expressed as means \pm S.E.M (standard error of the mean). Bacterial densities were $\log _{10}$ transformed before analysis of the means. Data were statistically evaluated using the analysis of variance (ANova) with post hoc Dunnet's t-test. Differences between groups were considered significant at $\mathrm{P}<0.05$.

\section{Results}

\section{Acute toxicity}

Single doses of E. prostrata extract elicited overt signs of toxicity from $15 \mathrm{gm} / \mathrm{kg}$ bw, progressively reducing different 
behavioural parameters-movement, sensitiveness to touch and noise and aversive behaviour-over a period of $48 \mathrm{~h}$. After this time, animal behaviour returned to normal. No significant change was observed in the quality and frequency of the faeces. The first animal death was observed with an extract dose of $10 \mathrm{gm} / \mathrm{kg}$ bw and the $\mathrm{LD}_{100}$ was found to be $25 \mathrm{gm} / \mathrm{kg}$ bw. Graphical and estimated $\mathrm{LD}_{50}$ were $16.25 \mathrm{gm} / \mathrm{kg}$ bw.

\section{Phytochemical properties}

In the water ethanol extract of $E$. prostrata, anthraquinones, flavonoids, phenols, phlobotannins, polysaccharides, saponins, tannins and terpenoids were identified. Alkaloids were not present in very high amounts.

\section{Susceptibility to Sd1}

In the agar diffusion method, the E. prostrata extracts were active against $S d 1$. The inhibition diameter $(\varnothing)$ began at $10 \mathrm{mg}$ extract $(\varnothing=8.5 \mathrm{~mm})$ and increased progressively up to $\varnothing=22.5 \mathrm{~mm}$ for $120 \mathrm{mg}$ of the extract; the inhibition diameter $(\varnothing)$ with norfloxacin was $22.5 \mathrm{~mm}$. The susceptibility of Sd1 to E. prostrata was determined, with the MIC and MBC values being 3500 and $12,000 \mu \mathrm{g} / \mathrm{ml}$, respectively.

\section{Antidiarrheic activity}

Animal behaviour, stool quality and mortality: Normal rats receiving only the food did not exhibit any diarrheic sign. Four hours after inoculum administration the animals became calm, less mobile and curled up. The first diarrheic faeces was emitted within $24 \mathrm{~h}$ (the $2^{\text {nd }}$ day) and thereafter the rats recovered their mobility progressively and presented greater aggressiveness, which decreased over the following days, except in the case of the diarrheic control and $10 \mathrm{mg} / \mathrm{kg}$ E. prostrata treated groups. Diarrheic stools were either soft or liquid, containing mucus or moulded and smooth and very often mucus-linked. At times, the faeces appeared molded and lumpy or presented blood marks. Stools of diarrheic rats emitted a fetid odour that attracted midges. By the $4^{\text {th }}$ day of treatment, the stench vanished and by day 5 , the midges stopped appearing. During the five days of therapy, no death was recorded with norfloxacin and E. prostrata extracts of 20 and $40 \mathrm{mg} / \mathrm{kg}$, whereas 40 and $100 \%$ deaths were registered on day 6 , respectively, in the $10 \mathrm{mg} / \mathrm{kg}$ E. prostrata and diarrheic control groups [Table 1].

\section{Table 1}

Effect of treatment with aqueous ethanol extract of Euphorbia prostrata (twice/day) on death rate of Shigella dysentariae type 1 diarrheic rats ( $n=5$ per group)

\begin{tabular}{|c|c|c|c|c|c|}
\hline \multirow{3}{*}{$\begin{array}{l}\text { Day after } \\
\text { treatment }\end{array}$} & \multicolumn{5}{|c|}{ Death rate (\%) } \\
\hline & \multirow[t]{2}{*}{$\begin{array}{c}\text { Diarrheic } \\
\text { control }\end{array}$} & \multirow[t]{2}{*}{$\begin{array}{l}\text { Noroxine } \\
(20 \mathrm{mg} / \mathrm{kg})\end{array}$} & \multicolumn{3}{|c|}{$\begin{array}{c}\text { Euphorbia } \\
\text { prostrata extract }\end{array}$} \\
\hline & & & $10 \mathrm{mg} / \mathrm{kg}$ & $20 \mathrm{mg} / \mathrm{kg}$ & $30 \mathrm{mg} / \mathrm{kg}$ \\
\hline 1 & 0 & 0 & 0 & 0 & 0 \\
\hline 2 & 0 & 0 & 0 & 0 & 0 \\
\hline 3 & 0 & 0 & 20 & 0 & 0 \\
\hline 4 & 40 & 0 & 20 & 0 & 0 \\
\hline 5 & 80 & 0 & 20 & 0 & 0 \\
\hline 6 & 100 & 0 & 40 & 0 & 0 \\
\hline
\end{tabular}

Stool bacterial density and frequency: In the stools of diarrheic control rats, Sd1 density increased significantly $(\mathrm{P}<0.01)$ from day 1 after diarrhea appeared: $3.9 \times 10^{9}$ and $2.6 \times 10^{9}$ by the $2^{\text {nd }}$ and $3^{\text {rd }}$ days, respectively, vs $1.2 \times 10^{9}$ administered. Compared with the diarrheic control and the initial value, the well-known antibiotic (norfloxacin) significantly $(P<0.01)$ reduced $S d 1$ growth from the $1^{\text {st }}$ up to $6^{\text {th }}$ day after start of therapy; it showed bactericidal effects. Similar to norfloxacin, E. prostrata inhibited bacterial growth in a dosedependant manner [Figure 1]. E. prostrata extract at $10 \mathrm{mg} / \mathrm{kg}$ inhibited bacterial growth by the $3^{\text {rd }}$ day and beyond, maintaining the $\mathrm{Sd} 1$ density at a level similar to that administered. The extract, at the doses of 20 and $40 \mathrm{mg} / \mathrm{kg}$, effectively $(P<0.01)$ reduced Sd1 density from $26 \mathrm{~h}$ of therapy and beyond. Similar to norfloxacin $(20 \mathrm{mg} / \mathrm{kg})$, the extract $(40 \mathrm{mg} / \mathrm{kg}$ ) reduced the bacterial density by $82 \%$. From the $2^{\text {nd }}$ day of treatment, the total faeces frequency, while increasing in control diarrheic rats, decreased in all the treated rats and significantly so from the $3^{\text {rd }}$ day [Figure 2A]. The extract at the doses of 20 and $40 \mathrm{mg} / \mathrm{kg}$, as well as the well-known drug norfloxacin, markedly reduced the diarrheic stool rate and frequency so that by the $5^{\text {th }}$ day diarrheic faeces frequencies were less than $10 \%$ of total stool, both in norfloxacin and $40 \mathrm{mg} / \mathrm{kg}$ extract treated rats [Figure 2B].

Gastrointestinal relaxant activity in vivo: Aqueous alcohol extract of $E$. prostrata significantly reduced the gastrointestinal propulsion of the charcoal solution meal. At oral doses 40 and $60 \mathrm{mg} / \mathrm{kg}$ there was $10 \%(P<0.05)$ and $17 \%$ $(P<0.01)$ inhibition, respectively [Table 2].

\section{Discussion}

The purpose of the present work was to establish the scientific rationale for the traditional use of $E$. prostrata extracts in treating infectious diarrhea. Antidiarrheic effects of an $80 \%$ ethanol extract were investigated using in vitro bacterial inhibition and in vivo activity against Shigella dysenteriae $\mathrm{A}_{1}$ - induced diarrhea in rats. Acute toxicity $\left(\mathrm{LD}_{50}\right.$ and overt signs) and phytochemical properties were also studied.

Figure 1: Shigella dysenteriae type 1 density ( $\log _{10}$ transformed) in diarrheic rat stools over 5 days of treatment (twice a day beginning $2 \mathrm{~h}$ after the appearance of diarrhea) with aqueous ethanol extract of Euphorbia prostrata (Ep) and norfloxacin (Norx). Data are the mean \pm SEM ( $n=5$ per group). ${ }^{*} P<0.05,{ }^{*} P<0.01$ compared with initial values at $2 \mathrm{~h}$; ${ }^{\mathrm{a}} P<0.05,{ }^{\mathrm{b}} P<0.01$ compared with diarrheic control

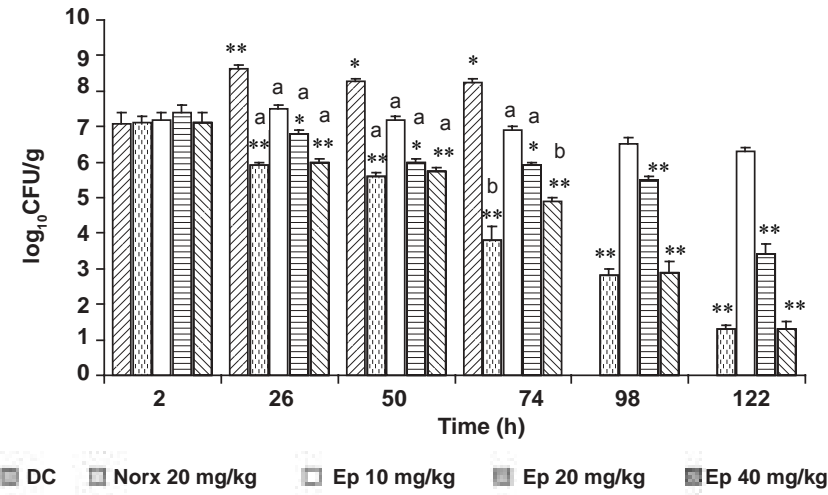


Figure 2: Total (A: number/day: nbr/day) and diarrheal (B: \% of total faeces frequency TS) stool frequency during the treatment (twice per day) of Shigella dysenteriae type 1 diarrheic rats with aqueous ethanol extract of Euphorbia prostrata (Ep) and norfloxacin (Norx). 0-5 days after extract administration. Data are the mean $\pm \operatorname{SEM}(n=5$ per group). ${ }^{*} P<0.05,{ }^{*} P<0.01$ compared with initial values at $2 \mathrm{~h}$; ${ }^{a} P<0.05$, ${ }^{\mathrm{b}} P<0.01$ compared with diarrheic control
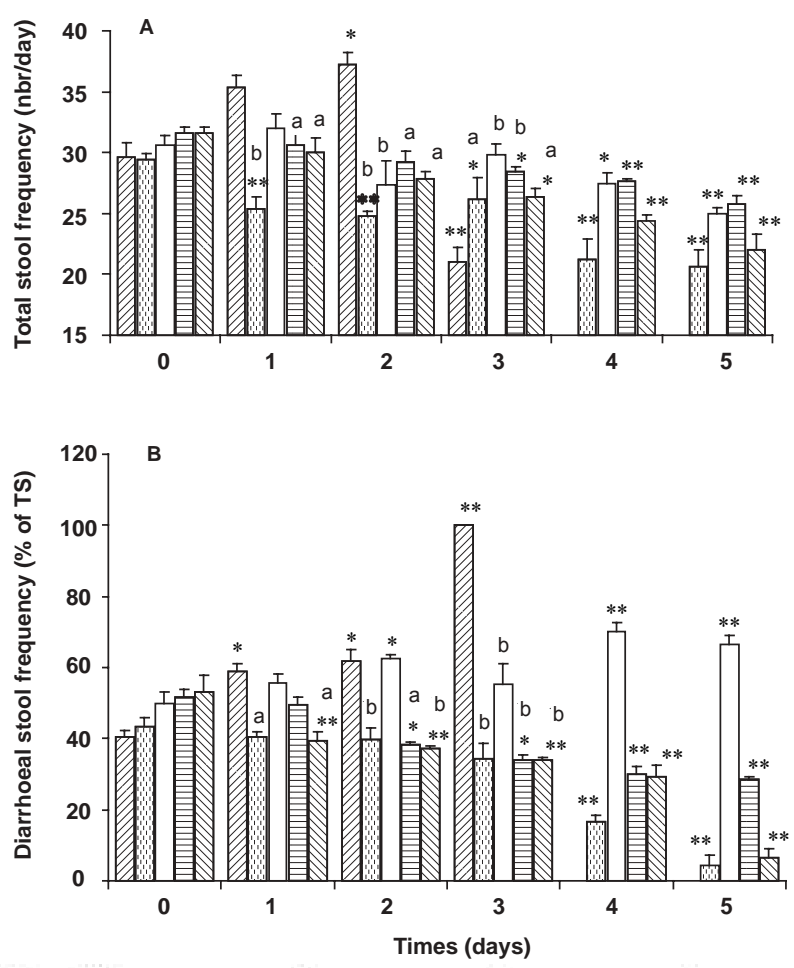

D DC

$\square$ Norx $20 \mathrm{mg} / \mathrm{kg} \square \mathrm{Ep} 10 \mathrm{mg} / \mathrm{kg} \square \mathrm{Ep} 20 \mathrm{mg} / \mathrm{kg}$

EEp $40 \mathrm{mg} / \mathrm{kg}$

\section{Table 2}

Effect of Euphorbia prostrate extract (Ep) on rat intestinal propulsion. Data are the mean $\pm \operatorname{SEM}(n=5$ per group)

\begin{tabular}{lccc}
\hline & Témoin & Ep $\mathbf{4 0 ~} \mathbf{~ g g / k g}$ & Ep $\mathbf{6 0 ~} \mathbf{~ m g} / \mathbf{k g}$ \\
\hline Total length $(\mathrm{cm})$ & $44.63 \pm 1.89$ & $47.28 \pm 2.73$ & $46.42 \pm 1.68$ \\
Charcoal covered & $34.27 \pm 1.32$ & $32.65 \pm 2.86$ & $29.59 \pm 1.43$ \\
length (cm) & & & \\
Progression rate (\%) & $76.79 \pm 1.67$ & $69.06 \pm 2.7^{*}$ & $63.74 \pm 1.52^{* *}$ \\
Inhibition rate (\%) & & 10.1 & 17 \\
\hline
\end{tabular}

${ }^{*} P<0.05$ and ${ }^{* *} P<0.01$, compared with control

The assayed doses represented $6 \times 10^{-4}, 12 \times 10^{-4}$ and $25 \times 10^{-4}$ of the oral $\mathrm{LD}_{50}$. Since aqueous ethanol extract of $\mathrm{E}$. prostrata at doses below $10 \mathrm{gm} / \mathrm{kg}$ did not provoke any change in the behaviour of normal animals and because the $\mathrm{LD}_{50}$ value was much higher than $5 \mathrm{gm} / \mathrm{kg}$, the extract can be considered safe for all practical purposes in the laboratory and for all medicinal uses, according to the WHO criteria. ${ }^{\mid 25]}$

The in vitro study showed the extract's inhibitory activity against $S d 1$, which was equiactive to norfloxacin. The extract's MIC and MBC values are seemingly high. These high values are almost certainly due to the fact that we used crude extract, since other studies have shown high MIC and MBC for the crude extracts of some shigellocidal plants. ${ }^{\mid 26]}$ A ratio of MBC/ MIC $<4$ could indicate a bacterial activity for $\mathrm{E}$. prostrata. ${ }^{20]}$ This was further confirmed by the $\mathrm{Sd} 1$ count in stools, where the decrease of bacterial population was similar to that obtained with norfloxacin treatment. By the $5^{\text {th }}$ day, the bactericidal actions of both $\mathrm{E}$. prostrata extract and the reference antibiotic norfloxacin were quite evident, with Sdl density in the stool becoming less than a hundred.

Many diarrheic rats developed signs such as curling up, soft stools, glairy/bloody or mucus-linked lumpy faeces, and faeces with a fetid odour that likely expressed the presence of pus. These signs are typical of infectious or 'invasive' diarrhea. ${ }^{[27]}$ Intestinal fermentation in diarrheic rats, by reducing the $\mathrm{pH}$ and increasing faecal bulk, ${ }^{|28|}$ raised the faeces frequency. Sdl swarming is responsible for shiga toxin production, which induces the production of an important reactive oxygen metabolite, the mediator nitric oxide (NO), which is implicated in the inflammation associated with diarrhea. ${ }^{[291}$ Toxin resulting from the bacterial swarming was suspected of being responsible for the limb weakness that occurred within $48 \mathrm{~h}$ in animals that did not pass stool ${ }^{[30]}$ and also for animal deaths. Norfloxacin (noroxin, $20 \mathrm{mg} / \mathrm{kg}$ ) and E. prostrata extract (20 and $40 \mathrm{mg} /$ $\mathrm{kg}$ ) reduced the bacterial population and at the same time may have slowed down the intestinal propulsion. Decrease in intestinal transit time could have led to exacerbation of enteroinvasive infections, but this might have been prevented by the bactericidal property of the extract and thereby resulted in the decrease in stool frequency.

Phytochemical assessment revealed the presence of phenols, saponins, flavonoids and tannins (and alkaloids) which possess antioxidant and anti-inflammatory activities. Flavonoids are responsible for the inhibition of intestinal motility and secretion, which could lead to a decrease in the frequency of wet faeces. ${ }^{[31]}$ Infections may be prevented by the antimicrobial properties of some compounds, such as anthraquinones, saponins and phenols. In the course of its intestinal anti-inflammatory action, some flavonoids inhibit inducible NO synthase. This action, since NO is responsible for the behavioural changes, could lead to the reduction in aggressiveness as well as the reduction of mucus-coated stool and bloody diarrhea. ${ }^{132,33 \mid}$ In addition to its use in diarrhea, E. prostrata is also traditionally used for the control of diabetes; the presence of tannins, polysaccharides, terpenoids, saponins, flavonoids (and alkaloids) in the extract probably explain its effect in this disease. E. prostrata extract progressively reduced the $\mathrm{Sd} 1$ density in the faeces. By the $4^{\text {th }}$ day of treatment, $40 \mathrm{mg} / \mathrm{kg}$ bw extract had reduced the Sd1 population by $48.5 \%$ and by $83.5 \%$ by the $6^{\text {th }}$ day. This progressive effect is of great importance because the toxin release that occurs with rapid destruction of microorganisms in vivo could lead to endotoxinic shock, which could result in high faeces frequency. ${ }^{[34]}$ On the other hand, the rapid decrease in diarrheic stool (from the $4^{\text {th }}$ day onwards) is responsible for the disappearance of midges. This is also of great significance, since flies are implicated in the transmission of shigellosis. ${ }^{[35]}$ The E. prostrata extract also abolished all the disorders observed in the Sd1-induced diarrhea. It is therefore possible that the aqueous alcohol extract of $E$. prostrata is effective against infectious diarrhea 
through antibacterial and/or antitoxin actions. These actions need to be elucidated with further investigations. Furthermore, the extract's antidiarrheic effect could also result from the combined slowing down of stool ejection.

In this study, the $\mathrm{S}$. dysenteriae type 1 strain was not resistant to the fluoroquinolone norfloxacin; the E. prostrata extract was found to be bactericidal; it inhibited behavioural changes, decreased stool frequency and prevented death in diarrheic animals. The bactericidal effect was comparable to that of the fluoroquinolone norfloxacin and was less sudden. All these antidiarrheic properties attest to the usefulness of E. prostrata in the treatment of diarrhea, especially infectious diarrheas such as Sd1-induced diarrhea.

\section{Acknowledgments}

We acknowledge the Centre Pasteur of Yaoundé - Cameroon, for providing us Shigella dysenteriae 1 strain and the University of Yaoundé I for the university research support fund (URSF2000-2002).

\section{References}

1. Sur D, Ramamurthy T, Deen J, Bhattacharya SK. Shigellosis: Challenges and management issues. Indian J Med Res 2004;120:454-62.

2. Dutta S, Dutta D, Dutta P, Matsushita S, Bhattacharya SK, Yoshida SI. Shigella dysenteriae serotype 1, Kolkatta, India. Emerg Infect Dis 2003;9:1471-4.

3. Naheed A, Kalluri P, Talukder KA, Faruque AS, Khatun F, Nair GB, et al. Fluoroquinolone-resistant Shigella dysenteriae type 1 in north-eastern Bangladesh. Lancet Infect Dis 2004;4:607-8.

4. Sivapalasingam S, Nelson JM, Joyce K, Hoekstra M, Angulo FJ, Mintz ED. High Prevalence of Antimicrobial Resistance among Shigella Isolates in the United States Tested by the National Antimicrobial Resistance Monitoring System from 1999 to 2002. Antimicrob Agents Chemother 2006;50:49-54.

5. Dutta S, Ghosh A, Ghosh K, Dutta D, Bhattacharya SK, Nair GB, et al. Newly emerged multiple antibiotic-resistant Shigella dysenteriae type 1 strains in and around Kolkatta, India, are clonal. J Clin Microbiol 2003;41:5833-4.

6. Dutta S, Kawamura Y, Ezaki T, Nair GB, lida KI, Yoshida SI. Alteration in the GyrA submit of DNA gyrase and the ParC submit of topoisomerase IV in Quinoloneresistant Shigella dysenteriae serotype 1 clinical isolates from Kolkatta, India. Antimicrob Agents Chemother 2005;49:1660-1.

7. Pazhani GP, Sarkar B, Ramamurthy T, Bhattacharya SK, Takeda Y, Niyogi SK Clonal multidrug-resistant Shigella dysenteriae type 1 strains associated with epidemic and sporadic dysenteries in eastern India. Antimicrob Agents Chemother 2004:48:681-4.

8. Ndihokubwayo JB, Baribwira C, Ndayiragije A, Poste B. Antibiotic sensitivity of 299 strains of shigella isolated in Burundi. Med Trop (Mars) 1996;56:37-40.

9. Cunin P, Tedjouka E, Germani Y, Ncharre C, Bercion R, Morvan J, et al. An epidemic of bloody diarrhea: Escherichia coli 0157 emerging in Cameroon? Emerg Infect Dis 1999;5:285-90.

10. Tarnagda Z, Diagbouga S, Sankara P, Kienou K, Yaro S, Van De Pierre P. Sensitivity to antibiotics strains of Shigella dysenteriae type 1 implicated in an outbreak in Burkina Faso. Medicine d'Afrique Noire 2001;48:141-4.

11. Mshana NR, Abbiw DK, Addae-Mensah I, Adjanohoun JE, Ahyimira, Ekpere JA, Enow-Orock EG, et al. Traditional Medecine and pharmacopoeia contribution to the revision of ethnobotanical and floristic studies in Ghana Organisation of African. Unity/Scientific, Technical and Research Commission 2000. p. 243

12. Tona L, Kambu K, Mesia K, Cimanga K, Apers S, De Bruyne T, et al. Biological screening of traditional preparations from some medicinal plants used as antidiarrheal in Kinshasa, Congo. Phytomedicine 1999;6:59-66.
13. Singla AK, Pathak K. Anti-inflammatory studies on Euphorbia prostrata. J Ethnopharmacol 1989;27:55-61.

14. Singla AK, Pathak K. Topical antiinflammatory effects of Euphorbia prostrata on carrageenan-induced footpad oedema in mice. J Ethnopharmacol 1990;29:291-4.

15. Kamgang R, Pouokam KE, Fonkoua MC, Penlap NB, Biwolé SM. Shigella dysenteriae type 1-induced diarrhea in Rats. Jpn J Infect Dis 2005;58:335-7.

16. Kamgang R, Pouoka Kamgne EV, Fonkoua MC, Penlap N Beng V, Biwole Sida M. Activities of aqueous extracts of Mallotus oppositifolium on Shigella dysenteriae A,-induced diarrhea in Rats. Clin Exp Pharmacol Physiol 2006;33:89-94.

17. Molle J. Limites de tolérence et toxicités de quelques amino-acides (formes $L$ et $D$ ). Amino-peptides-protéine, Cahier 24; Ed. A.E.C. 1986. p. 207-32.

18. Odebiyi OO, Sofowora EA. Phytochemical screening of Nigerian medicinal plants. Lloydia 1978;41:234-46.

19. Orech FO, Akenga T, Ochora J, Friis $\mathrm{H}$, Aagaard-Hansen J. Potential toxicity of some traditional leafy vegetables consumed in Nyang'oma Division, Western Kenya. Afr J Food Nutr Sc (AJFAND) 2005;5:1-13.

20. National Committee of Clinical and Laboratory Standards. Performance standards for antimicrobial susceptibility testing: fifteenth informational supplement. CLSI/ NCCLS Document M100-S15. Clinical and Laboratory Standards Institute: Wayne, $\mathrm{Pa} ; 2005$

21. Carbonnelle B, Denis F, Marmonier A, Pinon G, Vargues R. Bactériologies Médicales Techniques Usuelles. Simep: Paris; 1987.

22. Islam MS, Hossain MZ, Khan SI, Felsenstein A, Sack RB, Albert MJ. Detection of non-culturable Shigella dysenteriae 1 from artificially contaminated volunteers' fingers using fluorescent antibody and PCR techniques. J Diarrhoeal Dis Res 1997;15:65-70.

23. Fish JT, Pettibone GW. Influence of freshwater sediment on the survival of Escherichia coli and Salmonella sp. as measured by three methods of enumeration. Lett Appl Microbiol 1995;20:277-81.

24. Patnaik GK, Banaudha KK, Khan KA, Shoeb A, Dhawan BN. Spasmotytic activity of angelicin from Heracleum thomsoni. Planta Med 1987;53:517-20.

25. Diezi J. Principe de base et repercussion clinique. In: Schoderet M. Pharmacologie: des principes fondamentaux aux applications thérapeutiques. Frison-Roche, editor. $2^{\text {nd }}$ ed. Slatkine, Genève: Paris; 1992. p. 33-5.

26. Iwalokun BA, Gbenle GO, Adewole TA, Akinsinde KA. Shigellocidal properties of three Nigerian medicinal plants: Ocimum gratissimum, Terminalia avicennoides and Mormodica balsamina. J Health Popul Nutr 2001;19:331-5.

27. Carre D, Chapalain JC, Debonne JM, Klotz F. Diarrhées infectieuses aiguës. Encycl. Med. Chir, Maladies infectieuses, 8-003-V-10, 2000. p. 16.

28. Cooke C, Carr I, Abrams K, Mayberry J. Arrowroot as a treatment for diarrhea in irritable bowel syndrome patients: A pilot study. Arq Gastroenterol 2000; 37:20-4.

29. Sugi K, Musch MW, Di A, Nelson DJ, Chang EB. Oxidants potentiate $\mathrm{Ca}^{2+}$ - and cAMP-stimulated $\mathrm{Cl}$ secretion in intestinal epithelial T84 cells. Gastroenterology 2001;120:89-98.

30. Ludwig K, Karmali MA, Smith CR, Petric M. Cross-protection against challenge by intravenous Escherichia coli verocytotoxin 1 (VT1) in rabbits immunized with VT2 toxoid. Can J Microbiol 2002;48:99-103.

31. Di Carlo G, Autore G, Izzo AA, Maiolino P, Mascolo N, Viola P, et al. Inhibition of intestinal motility and secretion by flavonoids in mice and rats: Structure-activity relationships. J Pharm Pharmacol 1993;45:1054-9.

32. Balter-Seri J, Yuhas Y, Weizman A, Notech-Mozes Y, Kaminsky E, Ashkenazi S. Role of nitric oxide in the enhancement of pentylenetetrazole-induced seizures caused by Shigella dysenteriae. Infect Immun 1999;67:6364-8.

33. Camuesco D, Comalada M, Rodriguez-Cabezas ME, Nieto A, Lorente MD, Concha A, et al. The intestinal anti-inflammatory effect of quercitrin is associated with an inhibition in iNOS expression. Br J Pharmacol 2004;143:908-18.

34. Kernbaum S. Elements of infectious pathology, $6^{\text {th }}$ ed. Simep: Paris; 1996.

35. Gentilini M. Tropical medicine, $5^{\text {th }}$ ed. Flammarion Médecine-Sciences: Paris; 1993. 